Editorial

\title{
International Archives of Otorhinolaryngology Continuous Publication: Speeding up the Publication of Articles
}

\author{
Geraldo Pereira Jotz ${ }^{10}$ Aline Gomez Bittencourt ${ }^{2}$ () \\ ${ }^{1}$ Department of Morphological Sciences, Universidade Federal do Rio \\ Grande do Sul, Porto Alegre, RS, Brazil \\ ${ }^{2}$ Department of Otorhinolaryngology, Universidade Federal do \\ Maranhão, São Luís, MA, Brazil \\ ${ }^{3}$ Department of Otorhinolaryngology, Universidade de São Paulo, \\ São Paulo, SP, Brazil
}

Int Arch Otorhinolaryngol 2019;23:e253.

Following advances in electronic scientific communication, and with the aim to speed up the publication of articles, the International Archives of Otorhinolaryngology (IAO) has adopted the model of continuous publication. This new model enables the quick publication of articles; after approval and editorial production, the articles are automatically published online and made available in various databases (e.g. PubMed, SciELO, Scopus) without having to wait for the quarterly publication of the printed journal. ${ }^{1,2}$

International Archives of Otorhinolaryngology will continue to produce the printed edition periodically, with four issues per year (January, April, July, and October). However, in addition to this, the articles will be published and indexed in a continuous manner in the online databases, lending exposure and immediate access to these manuscripts. As such, we hope to retain the novelty of published works while broadening the exposure time of the research to increase the citations of articles, which will have a positive impact on the journal. $^{1}$

Regarding continuous publication, the main changes are:

- Although the content of the online version and the printed version will be the same, the numerical sequence of the pages will be different.

- The articles will be published using electronic pagination (e-pagination) and listed in chronological sequence.

(1D)Geraldo Pereira Jotz's ORCID is https://orcid.org/0000-00016289-7827.

(D) Aline Gomez Bittencourt's ORCID is https://orcid.org/0000-00031864-187X.

(D) Adilson Marcos Montefusco's ORCID is https://orcid.org/00000002-4896-5886.

Address for correspondence Prof. Geraldo Pereira Jotz, MD, PhD, Departamento de Ciências Morfológicas, Universidade Federal do Rio Grande do Sul, Av. Paulo Gama, 110-Farroupilha, Porto Alegre, RS, cep. 90040-060, Brazil (e-mail: iaorl@iaorl.org).

\author{
Adilson Marcos Montefusco ${ }^{3}$
}

- The printed version will have the usual numbering of pages, but the official citation will be the DOI (Digital Object Identifier) and/or the e-pagination (e.g., Int Arch Otorhinolaryngol 2019;23:e1-e5).

- The official citation will be shown on the first page of the printed version of each article.

In addition, the IAO uses social networks to give exposure and encourage discussion of its manuscripts. In a world where people are increasingly connected, it is necessary to use these technologies to stimulate interest in academic and research matters. "Liking," "commenting," and "sharing" scientific discoveries on social network platforms also serves as a metric for the involvement of the reader with the article.

Conflicts of Interest

The authors declare that there are no conflicts of interest.

\section{References}

1 Packer PAL, Santos Se Eliana Salgado DPS, et al. Acelerando a comunicação das pesquisas: as ações do SciELO [online]. SciELO em Perspectiva, 2016 [Cited 29 April 2019]. Available from: https://blog.scielo.org/blog/2016/03/10/acelerando-a-comunicacao-das-pesquisas-as-acoes-do-scielo/

2 Ferraz de Campos FP. Continuous publication: changing the publishing model. Autops Case Rep 2018;8(01):e2018017. Doi: 10.4322/ acr.2018.017 DOI https://doi.org/
10.1055/s-0039-1692698.
ISSN 1809-9777.
Copyright $\odot 2019$ by Thieme Revinter Publicações Ltda, Rio de Janeiro, Brazil

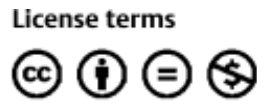

